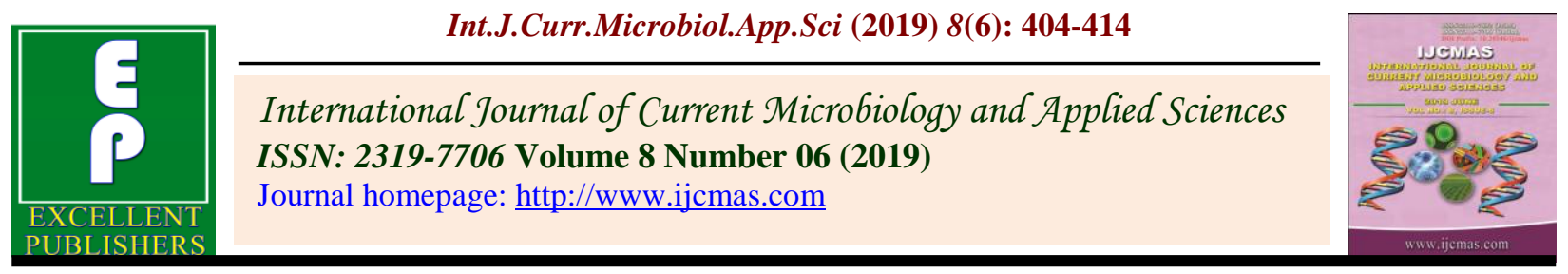

Original Research Article

https://doi.org/10.20546/ijcmas.2019.806.045

\title{
Distribution of Zinc in Plant Parts of Wheat Varieties with Varying Zinc Sensitivity at Different Growth Stages
}

\author{
Deepa Rawat*, Santosh Chandra Bhatt ${ }^{1}$, P.C. Srivastava ${ }^{2}$ and S.P. Pachauri ${ }^{3}$ \\ Department of Soil Science, College of Agriculture, GB Pant University of Agriculture and \\ Technology, Udham Singh Nagar, Uttarakhand-263945, India \\ *Corresponding author
}

\begin{tabular}{|l|}
\hline Key w or d s \\
Zinc, Growth stage, \\
Plant parts, Sandy \\
loam soil \\
\hline Article Info \\
\hline $\begin{array}{l}\text { Accepted: } \\
\text { 04 May 2019 } \\
\text { Available Online: } \\
\text { 10 June 2019 }\end{array}$ \\
\hline
\end{tabular}

\section{A B S T R A C T}

\begin{abstract}
A pot experiment was conducted in the green house of GB Pant University of Agriculture and Technology Pantnagar, to study the percent distribution of $\mathrm{Zn}$ on plant parts of four wheat varieties (UP 262, UP 2628. PBW 175 and UP2554) having varying Zn sensitivity at different growth stages. The soil used for pot experiment had sandy loam texture, 7.2 $\mathrm{pH}, 0.9 \%$ organic carbon and $0.47 \mathrm{mg}$ DTPA extractable $\mathrm{Zn}$ per kg soil. Each pot received recommended dose of $25 \mathrm{mg} \mathrm{N}, 11.2 \mathrm{mg} \mathrm{P}$ and $20.75 \mathrm{mg} \mathrm{K} \mathrm{kg}^{-1}$ soil. The pretreatment imposed consisted of a factorial combination of four wheat varieties and two Zn levels (0 and $10 \mathrm{mg} \mathrm{Zn} \mathrm{kg}^{-1}$ soil). There were two replications. Zinc was applied through a stock solution of $\mathrm{Zn} . \mathrm{SO}_{4} \cdot 7 \mathrm{H}_{2} \mathrm{O}$. Among the growth stages, the maximum average total uptake of $\mathrm{Zn}$ was noted at $\mathrm{D}_{3}(85.4 \mu \mathrm{g} / \mathrm{plant})$ followed by $\mathrm{D}_{4}(78.1 \mu \mathrm{g} / \mathrm{plant}) \mathrm{D}_{2}(35.6 \mu \mathrm{g} / \mathrm{plant})$ and $\mathrm{D}_{1}(10.6 \mu \mathrm{g} / \mathrm{plant})$. Application of $10 \mathrm{mg} \mathrm{Zn} \mathrm{kg}^{-1}$ soil increased the total average uptake of $\mathrm{Zn}$ per plant of wheat significantly by 31.4 percent over no application of $\mathrm{Zn}$. At harvesting, the highest percent accumulation of $\mathrm{Zn}$ was noted in straw (55.9\%) followed by grain (32.0\%) and root (12.1\%). Among all four varieties UP 262 and PBW 175 stored more of the $\mathrm{Zn}$ in non-edible parts of the plant whereas higher amount of $\mathrm{Zn}$ was recorded in the grain of UP 2628 and UP 2554).
\end{abstract}

\section{Introduction}

Zinc deficiency in crops is the common micronutrient problem world over; therefore, zinc malnutrition has become a major health burden among the resource deprived people (Takkar et al., 1990, Singh, 2011). About $50 \%$ of soils used for cereal production in the world contain low levels of plant available $\mathrm{Zn}$, which reduces not only grain yields but also nutritional quality of grain (Graham and Welch, 1996).
Jiang et al., (2007) showed that the final mass of $\mathrm{Zn}$ in the rice grain is a function of (1) $\mathrm{Zn}$ availability in the soil, (2) the capacity of the roots to take up $\mathrm{Zn}$, (3) the $\mathrm{Zn}$ demand of the growing crop, and (4) the partitioning of $\mathrm{Zn}$ within the crop. However, a large proportion of $\mathrm{Zn}$ is sequestered in the vegetative parts of the above-ground crop and in the panicle structure, so that relatively little $\mathrm{Zn}$ accumulates in the grains, in spite of the fact that stimulating $\mathrm{Zn}$ uptake after flowering increased $\mathrm{Zn}$ mass concentration in the grains. 
The supply of minerals to the developing cereal grain originates from two sources: first, as a result of direct uptake from the soil and second, from the remobilization of stored minerals in leaves as they senesce during the stage of grain filling (Uauy, 2006). Rootshoot translocation of $\mathrm{Zn}$ (Palmgren et al., 2008), grain filling and stem-panicle transfer (Jiang et al., 2008; Stomph et al., 2009), as well as the direct allocation of $\mathrm{Zn}$ from uptake during flowering (Jiang et al., 2007) need be addressed to provide better clue to the differential behaviour of different cultivars. Internal distribution and retention of $\mathrm{Zn}$ in different plant parts play a key role in determining grain $\mathrm{Zn}$ accumulation. Therefore knowledge of uptake dynamics and partitioning of $\mathrm{Zn}$ in different cultivars of wheat under deficient and sufficient conditions would help in devising the selection of varieties in order to overcome $\mathrm{Zn}$ malnutrition.

\section{Materials and Methods}

A pot experiment was conducted in the green house of GB Pant University of Agriculture and Technology Pantnagar, District Udham Singh Nagar, Uttarakhand. A bulk surface (0$15 \mathrm{~cm}$ ) samples of Mollisol was collected from portions of E1 plot of Norman E. Borlaug Crop research Centre of the University. The soil had sandy loam texture $7.2 \mathrm{pH}, 0.9$ percent organic carbon and 0.47 mg DTPA extractable $\mathrm{Zn}$ per $\mathrm{kg}$ soil. The processed soil (4 kg) was filled in plastic pots. Each pot received recommended dose of 25 $\mathrm{mg} \mathrm{N}, 11.2 \mathrm{mg} \mathrm{P}$ and $20.75 \mathrm{mg} \mathrm{K} \mathrm{kg}^{-1}$ soil through urea, potassium hydrogen phosphate and potassium chloride basally in liquid form. The pretreatment imposed consisted of a factorial combination of four wheat varieties (UP 262, UP 2628. PBW 175 and UP2554) and two $\mathrm{Zn}$ levels (0 and $10 \mathrm{mg} \mathrm{Zn} \mathrm{kg}{ }^{-1}$ soil). There were two replications. Zinc was applied through a stock solution of $\mathrm{Zn} \cdot \mathrm{SO}_{4} \cdot 7 \mathrm{H}_{2} \mathrm{O}$. All
Pots were watered and left for equilibration. When the soil moisture content was near field capacity, four pre-germinated rice seeds were sown in pots. The remaining amount of $\mathrm{N}$ (50 $\mathrm{mg} \mathrm{kg}^{-1}$ soil) was applied in two splits through urea in solution at 35 and 65 days after sowing. Plants were harvested after 30 , 60, 90 and 120 days of sowing. Roots were also recovered from the soil after shoot harvest at each level. To achieve this, pots containing roots were saturated with water then the whole soil mass along with roots was transferred down in a tray and passed through sieve $(0.5 \mathrm{~mm}$ diameter opening). The roots retained on sieve were collected and washed thoroughly with stilled water. After harvesting shoot and roots were thoroughly washed sequentially, first with tap water then in dilute $\mathrm{HCl}(0.1 \mathrm{~N})$ and finally in deionized water. Shoots were separated into upper lamina, upper leaf sheath, lower lamina, lower leaf sheath, stem, panicle and grains at different harvesting stages. Roots and the above mentioned shoot parts were dried at $60^{\circ} \mathrm{C}$ for 48 hours in an electric oven. Dry samples were then finally ground and digested with diacid mixture $\left(\mathrm{HNO}_{3}: \mathrm{HClO}_{4}\right.$, ratio 9:4) in hot plate, the digested material was diluted with distilled water, filtered through a Watman no. 42 filter paper and transferred to plastic vials. Digested samples were analysed for $\mathrm{Zn}$ concentration using atomic absorption spectrophotometer (GBC Avanta-M) and the content of $\mathrm{Zn}$ was expressed in terms of $\mathrm{mg}$ $\mathrm{kg}^{-1}$ plant tissue.

Percent distribution of $\mathrm{Zn}$ within each part of a plant was calculated by the following formula:

Percent accumulation of $\mathrm{Zn}$ in each plant part/plant=

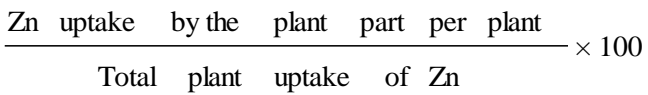




\section{Results and Discussion}

\section{Effect of Zn application on total Zn uptake $(\mu \mathrm{g} / \mathrm{plant})$ in wheat varieties at different growth stages}

The main effect of growth stages, $\mathrm{Zn}$ levels, and varieties significantly influenced the total uptake of $\mathrm{Zn}$ in wheat plants. Among the growth stages, the maximum average total uptake of $\mathrm{Zn}$ was noted at $\mathrm{D}_{3}(85.4 \mu \mathrm{g} /$ plant $)$ followed by $\mathrm{D}_{4}(78.1 \mu \mathrm{g} / \mathrm{plant}) \quad \mathrm{D}_{2} \quad(35.6$ $\mu \mathrm{g} /$ plant $)$ and $D_{1}(10.6 \mu \mathrm{g} /$ plant $)$. Application of $10 \mathrm{mg} \mathrm{Zn} \mathrm{kg}^{-1}$ soil increased the total average uptake of $\mathrm{Zn}$ per plant of wheat significantly by 31.4 percent over no application of $\mathrm{Zn}$. Among wheat varieties, the highest average total $\mathrm{Zn}$ uptake per plant was noted in UP $262(58.3 \mu \mathrm{g} / \mathrm{plant})$ followed by UP 2628 (55.6 $\mu \mathrm{g} / \mathrm{plant})$, UP 2554 (50.5 $\mu \mathrm{g} / \mathrm{plant})$ and $\mathrm{PBW} 175 \quad(45.4 \mu \mathrm{g} / \mathrm{plant})$ however; the differences in the total average Zn uptake per plant between UP 262 and UP 2628 or UP 2628 and UP 2554 or PBW 175 and UP 2554 were statistically not significant. The interaction effect of growth stages and $\mathrm{Zn}$ levels significantly influenced the total uptake of $\mathrm{Zn}$ per plant. With application of $10 \mathrm{mg} \mathrm{Zn}$ $\mathrm{kg}^{-1}$ soil, the total $\mathrm{Zn}$ uptake per plant of wheat increased significantly by $87.4 \%$ at $\mathrm{D}_{1}$, $48.5 \%$ at $\mathrm{D}_{3}, 23.6 \%$ at $\mathrm{D}_{2}$ and $27.5 \%$ at $\mathrm{D}_{4}$ over no $\mathrm{Zn}$ application. The interaction effect of growth stages and varieties also influenced the total $\mathrm{Zn}$ uptake per plant of wheat significantly (Table 1).

Effect of Zn application on percent distribution of $\mathrm{Zn}$ in different plant parts of wheat varieties at different growth stages

Percent distribution of $\mathrm{Zn}$ in different plant parts of wheat varieties at 30 days after sowing

The main effect of plant parts significantly influenced the percent distribution of $\mathrm{Zn}$ in wheat plants at 30 days after sowing whereas; the main effect of $\mathrm{Zn}$ levels and varieties had no statistically significant influence on the percent distribution of $\mathrm{Zn}$ in wheat plants at 30 days after sowing. Regarding the plant parts, percent distribution of $\mathrm{Zn}$ could be arranged in the following decreasing order; stem $(39.4 \%)>$ upper lamina $(29.8 \%)>$ lower lamina $(18.2 \%)>\operatorname{root}(12.6 \%)$. The interaction effect of plant parts and $\mathrm{Zn}$ levels significantly influenced the percent distribution of $\mathrm{Zn}$ in wheat plants at 30 days after sowing. Application of $\mathrm{Zn}$ at the rate of $10 \mathrm{mg} \mathrm{Zn} \mathrm{kg}^{-1}$ soil increased the uptake of $\mathrm{Zn}$ in stem by $23.8 \%$ in comparison to control (Table 2).

Percent distribution of $\mathrm{Zn}$ in different plant parts of wheat varieties at 60 days after sowing

The main effect of plant parts had significant influence on percent distribution of $\mathrm{Zn}$ in wheat plants at 60 days after sowing. As regards the plant parts, the highest percent distribution of $\mathrm{Zn}$ was noted in stem $(40.0 \%)$ followed by upper lamina (17.9\%), root (17.9 $\%)$, emerging ear $(16.4 \%)$ and lower lamina $(7.2 \%)$ however; the values noted in root, ear and upper lamina did not vary from each other significantly. The main effects of $\mathrm{Zn}$ levels and variety failed to influence the percent distribution of $\mathrm{Zn}$ in wheat varieties.

The interaction effect of plant parts and $\mathrm{Zn}$ levels significantly influenced the percentage of $\mathrm{Zn}$ in wheat plants at 60 days after sowing. Application of $\mathrm{Zn}$ at the rate of $10 \mathrm{mg} \mathrm{Zn} \mathrm{kg} \mathrm{g}^{-1}$ soil increased the percent distribution of $\mathrm{Zn}$ in stem and ear significantly by 23.8 and 12.2 percent, respectively over no application whereas; in roots it was decreased significantly by $20.8 \%$. The interaction effect of plant parts and varieties significantly influenced the percent distribution of $\mathrm{Zn}$ in wheat at 60 days after sowing. Also the interaction effect of plant parts, $\mathrm{Zn}$ levels and 
varieties significantly affected the distribution of $\mathrm{Zn}$ in percentage in wheat plants at 60 days after sowing (Table 3 ).

Percent distribution of $\mathrm{Zn}$ in different plant parts of wheat varieties at 90 days after sowing

The main effect of plant parts significantly influenced the percent distribution of $\mathrm{Zn}$ in wheat plants at 90 days after sowing whereas; the main effect of $\mathrm{Zn}$ levels and varieties had no significant influence on percent distribution of $\mathrm{Zn}$ in wheat plants at 90 days after sowing. Among the plant parts, the highest percent accumulation of $\mathrm{Zn}$ was noted in ear $(63.4 \%)$ followed by stem $(20.0 \%)$, root $(9.9 \%)>$ upper lamina $(4.5 \%)$ and lower lamina $(2.1 \%)$. The interaction effect of plant parts and $\mathrm{Zn}$ levels had significant influence on percent distribution of $\mathrm{Zn}$ in wheat plants at 90 days after sowing. With $\mathrm{Zn}$ application at the rate of $10 \mathrm{mg} \mathrm{Zn}^{-1} \mathrm{~kg}$ soil, the percent accumulation of $\mathrm{Zn}$ increased in stem significantly over no $\mathrm{Zn}$ application. The interaction effect of plant parts and varieties significantly affected the $\mathrm{Zn}$ distribution in wheat plants at 90 days after sowing. The interaction effect of plant parts, Zn levels and varieties significantly influenced the percent distribution of $\mathrm{Zn}$ in wheat plants at 90 days after sowing (Table 4).

Percent distribution of $\mathrm{Zn}$ in different plant parts of wheat varieties at 120 days after sowing

The main effect of plant parts had significant influence on percentage distribution of $\mathrm{Zn}$ in wheat plants at 120 days after sowing. As regards the plant parts, the highest percent accumulation of $\mathrm{Zn}$ was noted in straw (55.9 $\%)$ followed by grain $(32.0 \%)$ and root $(12.1$ $\%)$. The main effect of $\mathrm{Zn}$ levels and varieties had no significant influence on the percent distribution of $\mathrm{Zn}$ in wheat crop. The interaction effect of plant parts and $\mathrm{Zn}$ levels significantly influenced the percent distribution of $\mathrm{Zn}$ in wheat plants at 120 days after sowing. Zinc application at the rate of 10 $\mathrm{mg} \mathrm{Zn} \mathrm{kg}{ }^{-1}$ soil significantly increased the percent accumulation of $\mathrm{Zn}$ in grain but decreased it in roots and straw. The interaction effect of plant parts and varieties significantly influenced the percent distribution of $\mathrm{Zn}$ in wheat plants at 120 days after sowing (Table 5).

Table.1 Effect of Zn application on total uptake per plant ( $\mu \mathrm{g} / \mathrm{plant})$ in wheat varieties at different growth stages

\begin{tabular}{|c|c|c|c|c|c|c|c|c|c|c|c|c|c|c|c|}
\hline \multirow[t]{2}{*}{ Varieties } & \multicolumn{2}{|r|}{ D1 } & \multicolumn{3}{|c|}{ D2 } & \multicolumn{2}{|c|}{ D3 } & \multicolumn{3}{|c|}{ D4 } & \multicolumn{5}{|c|}{ Mean of plant part } \\
\hline & Zn0 & $\begin{array}{l}\mathrm{Zn} \\
\mathbf{1 0}\end{array}$ & Mean & Zn0 & $\begin{array}{l}\mathrm{Zn} \\
10\end{array}$ & Mean & Zn0 & $\begin{array}{l}\text { Zn } \\
10\end{array}$ & Mean & Zn0 & Zn10 & Mean & Zn0 & $\begin{array}{l}\mathrm{Zn} \\
10\end{array}$ & Mean \\
\hline UP 262 & 9.8 & 17.4 & 13.6 & 41.0 & 38.3 & 39.7 & 85.9 & 134.0 & 109.9 & 55.5 & 84.2 & 69.9 & 48.0 & 68.1 & 58.1 \\
\hline UP2628 & 6.3 & 10.2 & 8.2 & 28.4 & 41.4 & 34.9 & 71.4 & 82.7 & 77.0 & 92.5 & 111.8 & 102.2 & 49.7 & 61.5 & 55.6 \\
\hline PBW175 & 5.9 & 11.1 & 8.5 & 28.3 & 36.9 & 32.6 & 49.0 & 85.4 & 67.2 & 63.7 & 82.9 & 73.3 & 36.7 & 54.1 & 45.4 \\
\hline UP2554 & 7.6 & 16.8 & 12.2 & 29.7 & 40.8 & 35.3 & 68.6 & 106.2 & 87.4 & 62.9 & 71.2 & 67.0 & 42.2 & 58.8 & 50.5 \\
\hline Mean & 7.4 & 13.9 & 10.6 & 31.9 & 39.4 & 35.6 & 68.7 & 102.1 & 85.4 & 68.7 & 87.6 & 78.1 & 44.2 & 60.7 & 52.45 \\
\hline & & $\mathrm{D}$ & & $\mathrm{Zn}$ & & $\mathrm{V}$ & & $\begin{array}{l}\mathrm{Dx} \\
\mathrm{Zn}\end{array}$ & & $\mathrm{Zn} \times \mathrm{V}$ & & $\mathrm{D} \times \mathrm{V}$ & $\mathrm{D} \times 2$ & $n \times V$ & \\
\hline Sem \pm & & 2.4 & & 1.7 & & 2.5 & & 3.5 & & 4.9 & & 3.5 & & 0 & \\
\hline $\mathrm{CD}(\mathrm{p} \leq 0.05)$ & & 7.1 & & 5.0 & & 7.1 & & 10.0 & & NS & & 10.0 & & S & \\
\hline
\end{tabular}


Table.2 Effect of $\mathrm{Zn}$ application on percent distribution of Zinc in different plant parts of wheat at 30 days after sowing

\begin{tabular}{|c|c|c|c|c|c|c|c|c|c|c|c|c|c|c|c|}
\hline \multirow[t]{2}{*}{ Varieties } & \multicolumn{3}{|c|}{ Root } & \multicolumn{3}{|c|}{ Stem } & \multicolumn{3}{|c|}{ Lower lamina } & \multicolumn{3}{|c|}{ Upper lamina } & \multicolumn{3}{|c|}{ Mean of plant part } \\
\hline & Zno & Zn10 & Mean & Zn0 & Zn10 & Mean & Zn0 & Zn10 & Mean & Zn0 & Zn10 & Mean & Zn0 & Zn10 & Mean \\
\hline UP 262 & 25.8 & 10.1 & 18.0 & 35.0 & 47.8 & 41.4 & 16.0 & 16.7 & 16.4 & 23.2 & 25.4 & 24.3 & 25.0 & 25.0 & 25.0 \\
\hline UP2628 & 8.4 & 10.9 & 9.7 & 40.5 & 41.0 & 40.7 & 22.3 & 18.1 & 20.2 & 28.8 & 29.9 & 29.4 & 25.0 & 25.0 & 25.0 \\
\hline PBW175 & 11.6 & 8.8 & 10.2 & 40.4 & 43.3 & 41.9 & 21.3 & 14.6 & 17.9 & 26.7 & 33.2 & 30.0 & 25.0 & 25.0 & 25.0 \\
\hline UP2554 & 14.0 & 11.1 & 12.6 & 25.0 & 42.3 & 33.7 & 22.4 & 13.8 & 18.1 & 38.6 & 32.8 & 35.7 & 25.0 & 25.0 & 25.0 \\
\hline Mean & 15.0 & 10.2 & 12.6 & 35.2 & 43.6 & 39.4 & 20.5 & 15.8 & 18.2 & 29.3 & 30.3 & 29.8 & 25.0 & 25.0 & 25.0 \\
\hline & PP & & $\mathrm{Zn}$ & & $\mathrm{V}$ & & $\mathrm{PP} \times \mathrm{Zn}$ & & $\mathrm{Zn} \times \mathrm{V}$ & & $\mathrm{PP} \times \mathrm{V}$ & & $\mathrm{PP} \times \mathrm{Zn} \times \mathrm{V}$ & & \\
\hline SEm \pm & 1.3 & & 0.9 & & 1.3 & & 1.8 & & 2.6 & & 1.8 & & 3.6 & & \\
\hline$C D(p \leq 0.05)$ & 3.7 & & NS & & NS & & 5.2 & & NS & & 5.2 & & NS & & \\
\hline
\end{tabular}


Table.3 Effect of $\mathrm{Zn}$ application on percent distribution of Zinc in different plant parts of wheat at 60 days after sowing

\begin{tabular}{|c|c|c|c|c|c|c|c|c|c|c|c|c|c|c|c|c|c|c|}
\hline \multirow[t]{2}{*}{ Varieties } & \multicolumn{3}{|c|}{ Root } & \multicolumn{3}{|c|}{ Stem } & \multicolumn{3}{|c|}{ Lower lamina } & \multicolumn{3}{|c|}{ Upper lamina } & \multicolumn{3}{|c|}{ Ear } & \multicolumn{3}{|c|}{ Mean of plant part } \\
\hline & $\mathbf{Z 0}$ & $\mathbf{Z 1 0}$ & Mean & Zn0 & Zn10 & Mean & Zn0 & Zn10 & Mean & Zn0 & Zn10 & Mean & Zn0 & Zn10 & Mean & Zn0 & Z10 & Mean \\
\hline UP 262 & 17.1 & 15.3 & 16.2 & 39.3 & 42.0 & 40.7 & 8.9 & 8.0 & 8.5 & 13.2 & 17.8 & 15.5 & 18.9 & 16.7 & 17.8 & 19.5 & 20.0 & 19.7 \\
\hline UP2628 & 20.7 & 16.8 & 18.8 & 41.7 & 48.8 & 45.2 & 6.6 & 7.7 & 7.1 & 21.6 & 15.5 & 18.6 & 6.5 & 11.1 & 8.8 & 19.4 & 20.0 & 19.7 \\
\hline PBW175 & 19.6 & 17.2 & 18.4 & 29.3 & 41.2 & 35.3 & 7.6 & 6.2 & 6.9 & 18.6 & 20.9 & 19.8 & 26.2 & 14.9 & 20.6 & 20.3 & 20.1 & 20.2 \\
\hline UP2554 & 22.7 & 14.0 & 18.4 & 32.6 & 44.9 & 38.8 & 8.3 & 4.4 & 6.3 & 24.1 & 11.5 & 17.8 & 10.3 & 26.6 & 18.4 & 19.6 & 20.3 & 19.9 \\
\hline \multirow[t]{2}{*}{ Mean } & 20.0 & 15.8 & 17.9 & 35.7 & 44.2 & 40.0 & 7.8 & 6.6 & 7.2 & 19.4 & 16.4 & 17.9 & 15.5 & 17.3 & 16.4 & 19.7 & 20.1 & 19.9 \\
\hline & & PP & & $\mathrm{Zn}$ & & $\mathrm{V}$ & & & $\mathrm{PP} \times \mathrm{Zn}$ & & & $\mathrm{Zn} \times \mathrm{V}$ & & & $\mathrm{PP} \times \mathrm{V}$ & & & $P P \times Z n \times V$ \\
\hline SEm \pm & & 1.0 & & 0.6 & & 0.9 & & & 1.4 & & & 2.0 & & & 1.3 & & & 2.8 \\
\hline \multicolumn{2}{|c|}{$C D(p \leq 0.05)$} & 2.8 & & NS & & NS & & & 4.0 & & & NS & & & 3.6 & & & 8.1 \\
\hline
\end{tabular}


Table.4 Effect of Zn application on percent distribution of Zinc in different plant parts of wheat at 90 days after sowing

\begin{tabular}{|c|c|c|c|c|c|c|c|c|c|c|c|c|c|c|c|c|c|c|}
\hline \multirow[t]{2}{*}{ Varieties } & \multicolumn{3}{|c|}{ Root } & \multicolumn{3}{|c|}{ Stem } & \multicolumn{3}{|c|}{ Lower lamina } & \multicolumn{3}{|c|}{ Upper lamina } & \multicolumn{3}{|c|}{ Ear } & \multicolumn{3}{|c|}{ Mean of plant part } \\
\hline & $\mathbf{Z O}$ & $\mathbf{Z 1 0}$ & Mean & Zn0 & Zn10 & Mean & Zn0 & Zn10 & Mean & Zn0 & Zn10 & Mean & Zn0 & Zn10 & Mean & Zn0 & Z10 & Mean \\
\hline UP 262 & 5.2 & 6.2 & 5.7 & 20.5 & 29.1 & 24.8 & 2.3 & 1.9 & 2.1 & 4.6 & 4.2 & 4.4 & 67.9 & 59.4 & 63.7 & 20.1 & 20.2 & 20.2 \\
\hline UP2628 & 11.1 & 15.0 & 13.0 & 17.4 & 26.2 & 21.8 & 2.8 & 2.8 & 2.8 & 5.5 & 4.4 & 5.0 & 63.3 & 51.3 & 57.3 & 20.0 & 19.9 & 20.0 \\
\hline PBW175 & 12.3 & 8.6 & 10.4 & 12.3 & 17.9 & 15.1 & 1.3 & 1.7 & 1.5 & 3.3 & 4.1 & 3.7 & 70.6 & 67.5 & 69.0 & 19.9 & 20.0 & 20.0 \\
\hline UP2554 & 14.5 & 6.6 & 10.6 & 20.6 & 15.8 & 18.2 & 2.2 & 1.8 & 2.0 & 6.4 & 3.8 & 5.1 & 56.0 & 71.6 & 63.8 & 19.9 & 19.9 & 19.9 \\
\hline Mean & 10.8 & 9.1 & 9.9 & 17.7 & 22.3 & 20.0 & 2.1 & 2.1 & 2.1 & 4.9 & 4.1 & 4.5 & 64.4 & 62.4 & 63.4 & 20.0 & 20.0 & 20.0 \\
\hline & & PP & & $\mathrm{Zn}$ & & V & & & $\mathrm{PP} \times \mathrm{Zn}$ & & & $\mathrm{Zn} \times \mathrm{V}$ & & & $\mathrm{PP} \times \mathrm{V}$ & & & $\mathrm{PP} \times \mathrm{Zn} \times \mathrm{V}$ \\
\hline SEm \pm & & 0.8 & & 0.5 & & 0.7 & & & 1.1 & & & 1.6 & & & 1.0 & & & 2.2 \\
\hline $\mathrm{CD}(\mathrm{p} \leq \mathbf{0 . 0 5})$ & & 2.3 & & NS & & NS & & & 3.2 & & & NS & & & 2.9 & & & 6.4 \\
\hline
\end{tabular}


Table.5 Effect of Zn application on percent distribution of Zinc in different plant parts of wheat at 120 days after sowing

\begin{tabular}{|c|c|c|c|c|c|c|c|c|c|c|c|c|}
\hline \multirow[t]{2}{*}{ Varieties } & \multicolumn{3}{|c|}{ Root } & \multicolumn{3}{|c|}{ Straw } & \multicolumn{3}{|c|}{ Grain } & \multicolumn{3}{|c|}{ Mean of plant part } \\
\hline & $\mathbf{Z 0}$ & Z10 & Mean & Zn0 & Zn10 & Mean & Zn0 & Z10 & Mean & Zn0 & $\mathbf{Z 1 0}$ & Mean \\
\hline UP 262 & 12.8 & 10.1 & 11.5 & 69.2 & 63.4 & 66.3 & 18.0 & 26.6 & 22.3 & 33.3 & 33.3 & 33.3 \\
\hline UP2628 & 12.5 & 6.6 & 9.5 & 48.5 & 46.2 & 47.3 & 39.0 & 47.2 & 43.1 & 33.3 & 33.3 & 33.3 \\
\hline PBW175 & 16.1 & 8.4 & 12.2 & 68.5 & 61.5 & 65.0 & 15.4 & 30.1 & 22.8 & 33.3 & 33.3 & 33.3 \\
\hline UP2554 & 18.9 & 11.8 & 15.4 & 50.0 & 39.9 & 45.0 & 31.1 & 48.3 & 39.7 & 33.3 & 33.3 & 33.3 \\
\hline \multirow[t]{2}{*}{ Mean } & 15.1 & 9.2 & 12.1 & 59.0 & 52.7 & 55.9 & 25.9 & 38.0 & 32.0 & 33.3 & 33.3 & 33.3 \\
\hline & $\mathrm{PP}$ & & $\mathrm{Zn}$ & V & & $\mathrm{PP} \times \mathrm{Zn}$ & & $\mathrm{Zn} \times \mathrm{V}$ & & $\mathrm{PP} \times \mathrm{V}$ & & $\mathrm{PP} \times \mathrm{Zn} \times \mathrm{V}$ \\
\hline SEm \pm & 1.6 & & 1.3 & 1.9 & & 2.3 & & 3.3 & & 2.7 & & 4.6 \\
\hline$C D(p \leq 0.05)$ & 4.7 & & 3.8 & 5.4 & & 6.6 & & 9.3 & & 7.6 & & 13.2 \\
\hline
\end{tabular}


Effect of Zn application on total Zn uptake $(\mu \mathrm{g} / \mathrm{plant})$ in wheat varieties at different growth stages

Zinc uptake is the most important parameter statistically explaining the variation in $\mathrm{Zn}$ efficiency among the wheat genotypes (Hajiboland and Salehi, 2006). The data regarding uptake of $\mathrm{Zn}$ per plant showed that the $\mathrm{Zn}$ uptake was the highest in stem at 30 and 60 days after sowing whereas, at 90 days after sowing the highest uptake was recorded in ear followed by stem suggesting that at vegetative stage most of the $\mathrm{Zn}$ in above ground part of plant was accumulated in stem. The $\mathrm{Zn}$ uptake in upper lamina was recorded to be greater than lower lamina at 30 and 60 days after sowing whereas at the succeeding stage (i.e 90 days after sowing) the $\mathrm{Zn}$ uptake did not vary significantly for upper and lower lamina. Dang et al., (2010) also observed that accumulation of $\mathrm{Zn}$ in leaf blade was the highest among all the organs during early growing period similar to the results of our investigation. In late growing period, however, accumulation of $\mathrm{Zn}$ in grain was the highest. Application of $10 \mathrm{mg} \mathrm{Zn} \mathrm{kg}{ }^{-1}$ soil increased the average uptake of $\mathrm{Zn}$ in plant parts of wheat by $87.4 \%, 26.1 \%, 48.6 \%$ and $27.5 \%$ at 30, 60, 90 and 120 days after sowing. A comparison among the uptake of $\mathrm{Zn}$ in root at different growth stages revealed that $\mathrm{Zn}$ uptake in root was lower than all the above ground parts of plant at 30 days after sowing. The higher requirement of nutrient resulted in higher translocation of $\mathrm{Zn}$ to the shoot part at initial stage of plant growth in order to meet higher rate of growth. Thus, the early growing period from emergence to double ridge stage was one of the important periods of $\mathrm{Zn}$ absorption. In a field experiment, Dang et al., (2010) also recorded that the highest $\mathrm{Zn}$ concentration in aboveground organs of winter wheat occurred before double ridge stage, and declined sharply thereafter. At double ridge stage, the percentage of $\mathrm{Zn}$ accumulation in wheat plant reached $30-40 \%$ of the total accumulation. As regards the varieties, $\mathrm{Zn}$ uptake was the highest in UP 262 at 30 and 90 days after sowing whereas, at the termination of crop UP 2628 recorded the maximum uptake, also the $\mathrm{Zn}$ uptake in grain was found to be the highest in UP 2628 and the $\mathrm{Zn}$ uptake in grain in other three varieties did not differ from each other significantly. Though at 30 and 90 days after sowing the Zn uptake in UP 2628 and PBW 175 did not vary from each other but the uptake at harvesting stage was the maximum in UP 2628. Under $\mathrm{Zn}$ deficiency, $\mathrm{Zn}$ uptake could be better related to $\mathrm{Zn}$ efficiency because $\mathrm{Zn}$-efficient genotypes possibly have greater $\mathrm{Zn}$ uptake capacity under $\mathrm{Zn}$ deficiency. Enhancements in $\mathrm{Zn}$ uptake rate by roots and $\mathrm{Zn}$ utilization at the cellular level have been shown as important mechanisms affecting expression of high $\mathrm{Zn}$ efficiency in wheat (Rengel and Wheal, 1997).

\section{Effect of $\mathrm{Zn}$ application on percent distribution of $\mathrm{Zn}$ in different plant parts of wheat varieties at different growth stages}

Similar to the trend observed in $\mathrm{Zn}$ uptake per plant, the percent accumulation of $\mathrm{Zn}$ was the highest in stem at 30 and 60 days after sowing whereas, at 90 days after sowing the highest percentage of $\mathrm{Zn}$ was recorded in ear followed by stem however at harvest; the highest amount of $\mathrm{Zn}$ was accumulated in straw. Dang et al., (2010) also reported that $\mathrm{Zn}$ was mainly distributed in leaf blade and sheath before anthesis, especially in leaf blade, where the distribution percentage was above $50 \%$ before jointing, much higher than those in other plant parts. The percentage rapidly declined after booting and decreased to $13.6 \%$ at maturity. Similar to these observations, average percent accumulation of $\mathrm{Zn}$ in plant parts of wheat was found to be 25 
percent (mean of all plant parts) at initial plant growth stage $(30 \mathrm{~d})$ which reduced at $\mathrm{D}_{2}$ and $\mathrm{D}_{3}$ in the present study. At 90 days after sowing the percent accumulation of $\mathrm{Zn}$ was higher in lower lamina as compared to upper lamina because $\mathrm{Zn}$ is moderately mobile in plant due to which most of the $\mathrm{Zn}$ was mobilized from lower part of the plants to the upper parts. In wheat, $\mathrm{Zn}$ reaches the developing wheat grain via the phloem (Pearson and Rengel, 1995). Before $\mathrm{Zn}$ is loaded into the developing grain, the xylem bundles face discontinuity (Zee and O'Brien, 1970) and the xylem-phloem exchange occurs in the rachis and to a lesser extent in the peduncle, lemma and palea (Pearson and Rengel, 1995)b. In Zn inefficient varieties, the relatively lower capacity of loading $\mathrm{Zn}$ to the phloem in comparison to $\mathrm{Zn}$ efficient genotypes might be a limiting step.

It is concluded from these findings that among all four varieties UP 262 and PBW 175 stored more of the $\mathrm{Zn}$ in non-edible parts of the plant. Out of total $\mathrm{Zn}$ accumulation in aboveground plant parts, less than half of the percent accumulation of $\mathrm{Zn}$ was present in grains of these varieties. On the other hand, UP 2628 and UP 2554 were capable of producing the grains with higher percent accumulation of $\mathrm{Zn}$ as compared to UP 262 and PBW 175.

\section{References}

Dang, H.K, Li, R.Q., Sun, Y. H., Zhang, X.W. and Li, Y.M. 2010. Absorption, Accumulation and Distribution of Zinc in Highly-Yielding Winter Wheat. Agricultural Sciences in China, 9 (7): 965-973.

Hajiboland, R. and Salehi, S.Y. 2006. Characterization of $\mathrm{Zn}$ efficiency in Iranian rice genotypes. 1. Uptake efficiency. Gen. Appl. Plant Physiol., 32(3-4): 191-206.
Graham, R.D. and Welch, R.M. 1996. "Breeding for Staple Food Crops with High Micronutrient Density. Working Papers on Agricultural Strategies for Micronutrients No. 3. International Food Policy Research Institute, Washington, DC.

Jiang, W., Struik, P.C., Liang, J., Keulen, H., Zhao, M. and Stomph T.J. 2007. Uptake and distribution of root applied or foliar-applied $65 \mathrm{Zn}$ after flowering in aerobic rice. Ann Appl Biol. 150:383391.

Jiang, W., Struik, P.C., Zhao, M., Keulen, H. V., Fan, T.Q. and Stomph, T.J. 2008. Indices to screen for grain yield and grainzinc mass concentrations in aerobic rice at different soil-Zn levels. NJAS, 55-2.

Jiang, W., Struik, P.C., Keulen, H. V., Zhao, M., Jin, L.N. and Stomph, T.J. 2008. Does increased zinc uptake enhance grain zinc mass concentration in rice? Ann. Appl. Biol.,153: 135-147.

Palmgren, M.G., Clemens, S., Williams, L.E., Kramer, U., Borg, S., Schjorring, J.K and Sanders, D. 2008. Zinc biofortification of cereals: problems and solutions. Trends Plant Sci. 13:464473.

Pearson, J.N. and Rengel, Z. 1995. Uptake and distribution of ${ }^{65} \mathrm{Zn}$ and ${ }^{54} \mathrm{Mn}$ in wheat grown at sufficient and deficient levels of $\mathrm{Zn}$ and Mn II. During grains development. J Exp Bot, 46(7):841845.

Rengel, Z. and Graham, R.D. 1996. Uptake of zinc from chelate-buffered nutrient solutions by wheat genotypes differing in zinc efficiency. $J$ Exp Bot. 47(2):217-226.

Singh, M.V. 2010. Detrimental effect of zinc deficiency on crops productivity and human health. First Global Conference on Biofortification, Harvest Plus, Washington, USA. 
Stomph, T.J., Jiang, W. and Struik, P.C. 2009. Zinc biofortification of cereals: Rice differs from wheat and barley. Trends Plant Sci. 14:123-124.

Takkar, P.N., Chhibba, I.M. and Mehta, S.K. 1990. Two decades of micronutrient research in India. IISS, Bhopal, pp. 1 - 210.

Uauy, C. 2006. The high grain protein content gene Gpc-B1 accelerates senescence and has pleiotropic effects on protein content in wheat. J. Exp. Bot. 57: 27852794.

Zee, S.Y and O'Brien, T.P. 1970. A special type of tracheary element associated with 'xylem discontinuity' in the floral axis of wheat. Australian Journal of Biological Sciences, 23:783-791.

\section{How to cite this article:}

Deepa Rawat, Santosh Chandra Bhatt, P.C Srivastava and Pachauri, S.P. 2019. Distribution of Zinc in Plant Parts of Wheat Varieties with Varying Zinc Sensitivity at Different Growth Stages. Int.J.Curr.Microbiol.App.Sci. 8(06): 404-414. doi: https://doi.org/10.20546/ijcmas.2019.806.045 